\title{
Larval Survivorship and Settlement of Crown-of-Thorns Starfish (Acanthaster cf. solaris) at Varying Algal Cell Densities
}

\author{
Morgan S. Pratchett ${ }^{1, *}$, Symon Dworjanyn ${ }^{2}$, Benjamin Mos ${ }^{2}$, Ciemon F. Caballes ${ }^{1}$, \\ Cassandra A. Thompson ${ }^{1}$ and Shane Blowes ${ }^{1,3}$ \\ 1 ARC Centre of Excellence for Coral Reef Studies, James Cook University, Townsville, QLD 4811, Australia; \\ ciemon.caballes@my.jcu.edu.au (C.F.C.); cassandra.thompson@jcu.edu.au (C.A.T.); \\ shane.blowes@my.jcu.edu.au (S.B.) \\ 2 National Marine Science Centre, Southern Cross University, Coffs Harbour, NSW 2450, Australia; \\ Symon.Dworjanyn@scu.edu.au (S.D.); benjamin.mos@scu.edu.au (B.M.) \\ 3 Department of Zoology, George S. Wise Faculty of Life Sciences, Tel Aviv University, Tel Aviv 69978, Israel \\ * Correspondence: morgan.pratchett@jcu.edu.au; Tel.: +61-747-81-5747
}

Academic Editors: Sven Uthicke and Michael Wink

Received: 14 November 2016; Accepted: 4 January 2017; Published: 10 January 2017

\begin{abstract}
The dispersal potential of crown-of-thorns starfish (CoTS) larvae is important in understanding both the initiation and spread of population outbreaks, and is fundamentally dependent upon how long larvae can persist while still retaining the capacity to settle. This study quantified variation in larval survivorship and settlement rates for CoTS maintained at three different densities of a single-celled flagellate phytoplankton, Proteomonas sulcata $\left(1 \times 10^{3}, 1 \times 10^{4}\right.$, and $1 \times 10^{5}$ cells $/ \mathrm{mL}$ ). Based on the larval starvation hypothesis, we expected that low to moderate levels of phytoplankton prey would significantly constrain both survival and settlement. CoTS larvae were successfully maintained for up to 50 days post-fertilization, but larval survival differed significantly between treatments. Survival was greatest at intermediate food levels $\left(1 \times 10^{4}\right.$ cells $\left./ \mathrm{mL}\right)$, and lowest at high $\left(1 \times 10^{5}\right.$ cells $\left./ \mathrm{mL}\right)$ food levels. Rates of settlement were also highest at intermediate food levels and peaked at 22 days post-fertilization. Peak settlement was delayed at low food levels, probably reflective of delayed development, but there was no evidence of accelerated development at high chlorophyll concentrations. CoTS larvae were recorded to settle 17-43 days post-fertilization, but under optimum conditions with intermediate algal cell densities, peak settlement occurred at 22 days post-fertilization. Natural fluctuations in nutrient concentrations and food availability may affect the number of CoTS that effectively settle, but seem unlikely to influence dispersal dynamics.
\end{abstract}

Keywords: Acanthaster; coral reefs; food limitation; larval competency; planktonic larval duration (PLD)

\section{Introduction}

Sessile and benthic marine invertebrates are fundamentally dependent on the larval phase of their lifecycle for dispersal away from natal reefs, which is important for enabling colonization of new habitats, recolonization following population depletion, and genetic exchange among sub-populations [1,2]. Despite the short larval duration of most marine organisms (days to months), larvae may be dispersed over great distances [2]. Importantly, ecologically and evolutionarily significant levels of genetic exchange occur over very large (even oceanic) scales (e.g., [3]). There is however, evidence for some species that most of the larvae (up to 60\%) settling on a given reef are of local origin [4], implying that most larvae may not even travel beyond the confines of a single reef. Ultimately, there may be two distinct modes (short versus long, retention versus dispersal, 
or self-recruitment versus departure) in the range of dispersal distances for individual species [5]. Variation in dispersal within and among cohorts of larvae will have a critical influence on population dynamics and persistence for widespread species [5].

For crown-of-thorns starfish (Acanthaster spp.), hereafter referred to as CoTS, the proportion of larvae that are retained versus dispersed is important in understanding both the initiation and spread of population outbreaks [6-8]. Strong larval retention is fundamental to the progressive accumulation of CoTS within a given location, which is increasingly viewed as the predominant mechanism that gives rise to primary outbreaks [6,7]. On the Great Barrier Reef (GBR). Woolridge and Brodie [7] suggested that rates of larval retention vary among years with changes in ENSO driven ocean current velocities, and that initiation of outbreaks is coincident with periods of "strong local clustering", where there are high levels of retention at individual reefs or within tightly packed reef clusters. Once established, initial outbreak populations then give rise to large numbers of larvae that often spread to other reefs. Moreover, dispersal to other downstream (generally southerly) reefs is facilitated by increases in ocean currents and relaxation of the strong local clustering [7]. This larval retention hypothesis [7] is particularly tenable because it explains why major flood events and nutrient enrichment in near reef waters do not necessarily initiate outbreaks of CoTS, but may facilitate rapid proliferation and spread of outbreaks across the GBR. Moreover, changes in rates of larval retention versus dispersal may be facilitated by shifts in larval development rates and settlement behaviour due to natural fluctuations in nutrients and food availability. Yet, little is known about how food availability may influence developmental rates for crown-of-thorns starfish larvae.

Aside from local hydrodynamics and larval behaviour, two fundamental parameters that influence the retention versus dispersal of marine larvae are (i) the minimum pre-competency period, which is the time taken (in hours or days) for larvae to complete necessary development prior to being physiologically and morphologically capable of settling; and (ii) the maximum competency period, which is the longest period that larvae can remain in the plankton (often dictated by their initial energy reserves and/or capacity to sustain themselves) and still retain the ability to successfully settle. The minimum pre-competency period has a strong bearing on the extent to which larvae are likely retained on their natal reef(s), whereas the maximum competency period is fundamental in establishing how far larvae could potentially spread. Marine fishes typically exhibit very narrow ranges in their planktonic larval duration (PLD) (i.e., only a few days separate the maximum competency period and minimum pre-competency period), especially for species with short pre-competency periods [9]. For fishes, therefore, individual variation in dispersal is largely attributed to traits that influence their physical capacity (e.g., swimming performance and navigation ability) to extend dispersal distances or return to their natal reefs despite limited differences in larval duration [5]. Marine invertebrates however, may be competent for highly protracted periods, such that individuals from the same cohort may settle anywhere from several hours to many months after fertilization $[10,11]$ depending on their nutritional status and exposure to settlement cues.

Acanthaster spp. have been successfully cultured under laboratory conditions since the early 1970s [12], largely for the purposes of understanding their developmental biology. Initial rearing experiments, where larvae were maintained at $24-25^{\circ} \mathrm{C}$ for the formative stages of development (until larvae reached late bipinnaria at day 21) resulted in PLD estimates of 30-47 days, with a mean of 38 days [12]. However, CoTS generally spawn only when sea surfaces temperatures are $\geq 27^{\circ} \mathrm{C}$ [13], and larvae develop more quickly at higher temperatures [14,15]. Lamare et al. [14] showed that development rates of CoTS from Australia's GBR were maximized at or above $28.7^{\circ} \mathrm{C}$, at which temperature, larvae may complete development and be competent to settle within 12 to 14 days [16].

Aside from the effects of temperature, variation in larval survivorship and rates of larval development for CoTS are also influenced by nutrient concentrations and food availability (e.g., [17]). One of the foremost hypotheses asserting that outbreaks of CoTS are exacerbated (if not caused) by anthropogenic activities, the larval starvation hypothesis, links the initiation and/or spread of outbreaks to elevated nutrient concentrations caused by intensive agriculture in adjacent catchments $[18,19]$. 
This idea is largely predicated on marked differences in the proportion of CoTS larvae that complete development over relatively moderate ranges of chlorophyll concentrations [19]. Fabricius et al. [19] showed that developmental success is effectively zero at $<0.25 \mu \mathrm{g} \cdot \mathrm{L}^{-1}$ chlorophyll compared to $100 \%$ at $2-4 \mu \mathrm{g} \cdot \mathrm{L}^{-1}$ chlorophyll. It is suggested therefore, that elevated chlorophyll concentrations caused by run-off from modified catchments during intensive storms will reduce constraints on larval survivorship and recruitment imposed by normally low-levels of nutrients and food [19]. More recent studies have, however, shown that very high levels of nutrients are deleterious to larval development for CoTS, while larval growth and development are maximized at close to normal background concentrations of chlorophyll [20]. These studies $[17,20]$ compare the size and fate of CoTS larvae at specific time intervals (e.g., at 4 days old) across different nutrient concentrations, but it is unknown to what extent nutrient concentrations may influence the competency periods, and therefore dispersal potential, of crown-of-thorns starfish larvae.

In this study, we quantify variation in larval survivorship and settlement rates for CoTS maintained at three different food treatments. Based on the larval starvation hypothesis (e.g., [19]), we expected that starfish subject to very low food availability would develop more slowly and have lower survivorship compared to larval cultures maintained with higher cell densities of phytoplankton. Accordingly, we expected that increases food availability would increase rates of development, thereby reducing the minimum pre-competency period. High food availability meanwhile, are also expected to greatly extend the maximum competency period, both by increasing rates of survivorship and provisioning larvae with resources necessary for metamorphosis at settlement. It is known however, that excess food can inhibit filter feeding and digestion by CoTS larvae, ultimately leading to arrested development and high levels of mortality [17]. While previous studies (e.g., [17,20]) have compared the size, development and survival of larvae of CoTS at set intervals in their development (to explicitly test the effects of food availability among individuals of equivalent age), this study looks at overall longevity and competency of larvae to test whether increased food availability will expedite development, potentially leading to higher rates of larval retention. Alternatively, elevated nutrients and food availability may extend the maximum competency period for CoTS larvae and therefore, facilitate greater dispersal.

\section{Materials and Methods}

\subsection{Larval Culture and Settlement Experiments}

Adult Acanthaster cf. solaris [21] were collected from the GBR near Cairns, Australia $\left(16^{\circ} 55^{\prime} \mathrm{S}\right.$, $145^{\circ} 46^{\prime}$ E) by control divers employed by the Association of Marine Park Tourism Operators (AMPTO) and air freighted to the National Marine Science Centre, Southern Cross University at Coffs Harbour, NSW, Australia. Eggs from three female starfish were collected, pooled and fertilized using sperm from three males, following Kamya et al. [22]. Fertilized embryos were reared for two days in an aerated 300-L cylindro-conical tank at $\sim 28^{\circ} \mathrm{C}$ at a density of 2.5 larvae $\mathrm{mL}^{-1}$. After 2 days (coinciding with the onset of feeding), larvae were distributed among replicate 1-L cylindro-conical containers and subject to one of three different feeding/nutrient treatments. Larvae were reared in 1-L cylindro-conical containers in filtered $(5 \mu \mathrm{m})$ seawater at a density of 1.2 larvae $\cdot \mathrm{mL}^{-1}$ and fed Proteomonas sulcata at 1 , 10 and $100 \times 10^{3}$ cells $\cdot \mathrm{mL}^{-1}$, respectively (Wolfe et al. 2015 [20]). Proteomonas sulcata is a single-celled flagellated phytoplankton that is 7-10 $\mu \mathrm{m}$ long, and within the size range of food particles readily consumed by CoTS $[23,24]$. There were 10 replicates for each distinct algal density and chlorophyll concentration. Containers were maintained in a climate-controlled room at $28.5^{\circ} \mathrm{C}\left( \pm 0.2^{\circ} \mathrm{C}\right)$. Larvae were fed daily after a $100 \%$ water exchange. Larval cultures were moved to new containers every 2-3 days.

To follow survival, the number of larvae in each container was quantified every $2-3$ days by extrapolating the number of larvae counted in $20 \mathrm{~mL}$ subsamples taken from each container. However, when larval density was $<0.1$ larvae $\cdot \mathrm{mL}^{-1}$, all of the larvae were counted. Survival rates were 
calculated as the number of larvae remaining out of the total added to the container at the start of the experiment, while also adjusting for larvae removed from the containers for settlement assays and for larvae that spontaneously settled in the containers, from 17 days onwards. Importantly, estimates of survivorship in this laboratory-based study are likely to be much higher than expected in the field, where sustained predation on gametes and larvae [25] may result in very high rates of mortality [26].

Settlement assays were undertaken from 17 days post-fertilization, which was the first day at which late-stage brachioloaria with well-developed rudiments were observed across all treatments, thereby enabling comparisons of settlement rates across treatments. Settlement assays were conducted in $36 \mathrm{~mm}$ plastic petri dishes containing $4 \mathrm{~mL}$ of fresh seawater, and a $1 \mathrm{~cm}^{2}$ crustose coralline algae (CCA) encrusted polycarbonate plate to induce settlement [27]. For each assay, there were three replicates from each larval container with 10 larvae per replicate, although this was reduced to one replicate when there were less than 100 larvae in a container. Settlement rates were quantified after $48 \mathrm{~h}$. All newly settled, 5-arm juveniles were photographed in seawater, aboral side up, and flat to the plane of focus using a camera (Olympus DP26) mounted on a stereomicroscope. Area of the juveniles was measured from the photographs using Image-J image analysis software (National Institutes of Health, Bethesda, MD, USA). Settlement assays were conducted 17, 22, 29, 36 and 43 days post-fertilization. Thereafter, there were too few larvae in any of the treatments to effectively test for settlement.

\subsection{Statistical Analyses}

Larval survival was estimated from sub-sampling rather than a complete census, so traditional methods of survival analysis were not appropriate. Instead, we modeled counts using non-linear splines (GAMMs; [28]) assuming Poisson error and a log link function. More specifically, we examined counts of surviving larvae using models with a categorical treatment effect, and treatment specific cubic regression splines; splines were estimated with shrinkage, meaning that smoothness selection can zero a term completely [28], and the number of knots was set to 4 for all smooths to prevent over-fitting. Additionally, replicate was fitted as a random effect. All models were estimated using the gamm4 package [29]. Overall goodness-of-fit was checked using standard techniques (e.g., residuals plotted against all explanatory variables and fitted values from the models).

Settlement assay data were reduced to observations where the numbers of larvae available per settlement assay were known before analysis. This resulted in a data set of 292 observations for all age-treatment combinations, with replication at each combination ranging from 1 to 30 . Due to this unbalanced design, we modeled the probability of successful settlement using a generalized linear mixed effects model (GLMM) with binomial error and a logit link function. Age (continuous) and treatment (categorical: three levels) were modeled as fixed effects; replicate and assay were modeled as random effects, with assay (up to three per replicate) nested within replicate (up to 10 replicates per age-treatment combination); age was centered by subtracting the mean age from all observed ages before model fitting. To examine potential nonlinearities in settlement probability with larval age and age-by-treatment interactions, we fit a model with a second-order term for age, and an age-treatment interaction term. Initial model fits suggested that data were over-dispersed, and the beta-binomial was supported over the binomial distribution (likelihood ratio test: $X^{2}=84.62, d f=1, p<0.001$ ). Models were estimated using maximum likelihood in the glmmADMB package [30,31] in R 3.3.1 [32]. We assessed the significance of fixed effects using type II Wald's chi-square tests, and the fit of models and their conformity to statistical assumptions were visually inspected using standard techniques (i.e., plots of residuals versus fitted values, and all covariates).

\section{Results}

\subsection{Larval Survival}

Larval crown-of-thorns starfish were successfully maintained in 1-L cylindro-conical containers for up to 50 days post-fertilization, though most larvae had died or settled within 30 to 40 days. Mean larval 
survival differed significantly between treatments (i.e., the parametric treatment component was significant: $X^{2}=470, d f=2, p<0.001$; see Table 1 for individual terms), and was greatest at intermediate $\left(1.0 \mu \mathrm{g} \cdot \mathrm{L}^{-1}\right)$ chlorophyll concentrations, followed by the low and the high chlorophyll concentrations (Table 1; Figure 1). There were initially high rates of larval mortality across all treatments, but mortality rate decreased (between approximately 15 and 22 days) at low to intermediate chlorophyll concentrations, before increased rates of mortality after 30 days (Figure 1). Larval survival initially decreased at similar rates for the high and low food treatments, but the initial loss of larvae was slower in the medium food treatment. At high algal concentrations, high rates of early post-fertilization mortality continued in an exponential-like decay throughout the experiment, such that the maximum longevity of larvae was only 36 days.

Table 1. Estimates of the (a) parametric coefficients and (b) the approximate significance of the smooth terms of the survival model (Poisson error distribution, log link functions). Parametric intercept term represents the low food treatment.

\begin{tabular}{lcccc}
\hline (a) Parametric Coefficients & Estimate & Std. Error & $p$ & \\
\hline Intercept & 4.59 & 0.05 & $<2 \times 10^{-16}$ & \\
treatment (medium) & 0.51 & 0.04 & $<2 \times 10^{-16}$ & \\
treatment (high) & -3.50 & 0.23 & $<2 \times 10^{-16}$ & \\
\hline (b) Smooth Terms & edf & Ref.df & Chi.sq & $p$ \\
\hline s(time) treatment (low) & 2.997 & 3 & 12,436 & $<2 \times 10^{-16}$ \\
s(time) treatment (medium) & 2.998 & 3 & 9927 & $<2 \times 10^{-16}$ \\
s(time) treatment (high) & 2.985 & 3 & 10,680 & $<2 \times 10^{-16}$ \\
\hline
\end{tabular}
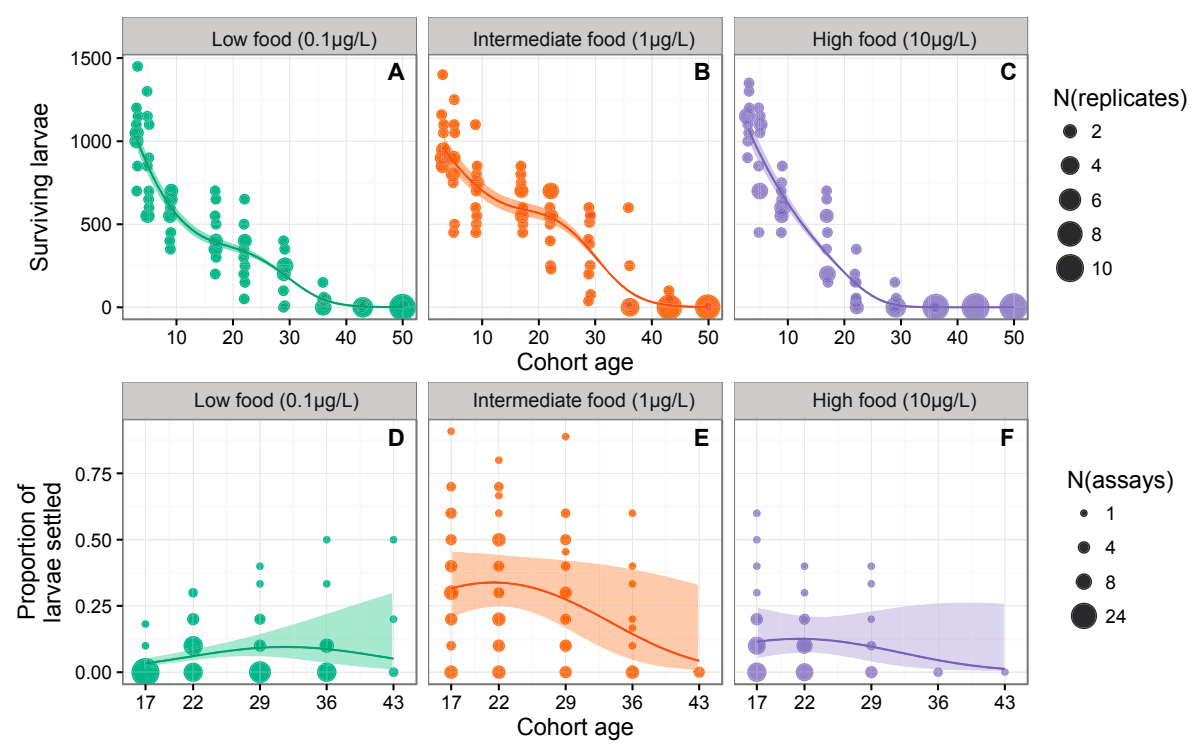

Figure 1. Non-linear effects of increasing food availability on larval survivorship and settlement for crown-of-thorns starfish (Acanthaster cf. solaris) from Australia's Great Barrier Reef: (A-C) Absolute larval survivorship between 1 and 50 days post-fertilization for each of ten replicate cultures maintained at low $\left(0.1 \mu \mathrm{g} \cdot \mathrm{L}^{-1}\right)$, medium $\left(1.0 \mu \mathrm{g} \cdot \mathrm{L}^{-1}\right)$ or high $\left(10 \mu \mathrm{g} \cdot \mathrm{L}^{-1}\right)$ chlorophyll concentrations; (D-E) Proportion of larvae ( $n=10-30$ per culture) that successfully settled 17, 22, 29, 36 and 43 days post-fertilization for each of the ten replicate cultures maintained at low $\left(0.1 \mu \mathrm{g} \cdot \mathrm{L}^{-1}\right)$, medium $\left(1.0 \mu \mathrm{g} \cdot \mathrm{L}^{-1}\right)$ or high $\left(10 \mu \mathrm{g} \cdot \mathrm{L}^{-1}\right)$ chlorophyll concentrations. Lines show the predictions from the GAMMs fit to the survival data (A-C), and from the GLMMs fit to the settlement data (D-F); shaded areas depict $95 \%$ confidence intervals (all panels). 


\subsection{Probability of Successful Settlement}

Although larvae were maintained for up to 50 days post-fertilization, too few larvae persisted beyond 43 days post-fertilization to enable effective tests of competency. Even at 43 days post-fertilization, few of the larvae tested were capable of settling, and mainly from the low algal food treatment. The probability of a larva successfully settling depended on both age and food treatment (Figure 1). We found strong evidence for settlement probability being a non-linear function of age (age ${ }^{2}$ term was significant: $X^{2}=6.35, d f=1, p=0.01$ ), and there was strong support for an interaction between food treatment and age $\left(X^{2}=15.45, d f=2, p<0.001\right)$. Settlement probability was highest for the medium food treatment $(1 \mu \mathrm{g} / \mathrm{L})$ and peaked at around 22 days. Settlement probability was also greatest around the 22-day point for the high food $(10 \mu \mathrm{g} / \mathrm{L})$ treatment, but declined precipitously thereafter and none of the larvae from this treatment settled on days 36 and 43. For larvae from the low food treatment $(0.1 \mu \mathrm{g} / \mathrm{L}$ chlorophyll A), settlement probability peaked at around 30 days post-fertilization, and some larvae successfully settled at day 43 . However, peak settlement probabilities in the low food treatment were much lower than those observed in the intermediate food treatment (Figure 1).

The algal concentrations to which larvae were exposed appeared to affect the size of CoTS that settled at 17 days, whereby starfish from the low $\left(0.1 \mu \mathrm{g} \cdot \mathrm{L}^{-1}\right)$ chlorophyll concentration were one-third of the size $\left(0.13 \mathrm{~mm}^{2} \pm 0.03 \mathrm{SE} ; n=2\right)$ of the settled starfish from intermediate $\left(0.43 \mathrm{~mm}^{2} \pm 0.60 \mathrm{SE}\right.$; $n=10)$ and high $\left(0.44 \mathrm{~mm}^{2} \pm 0.56 \mathrm{SE} ; n=8\right)$ algal concentrations. However, too few larvae settled in the low food treatment to enable robust statistical comparisons of size at settlement, and any effect of algal treatment on size at settlement disappeared after 22 days post-fertilization.

\section{Discussion}

\subsection{Non-Linear Effects of Increasing Food Availability on Larval Survivorship and Settlement}

This study shows that variation in phytoplankton concentrations has a significant effect on both larval survivorship and settlement rates for CoTS, as would be expected for planktotrophic larvae $[17,20]$. It was also apparent that increasing concentrations of phytoplankton can expedite development such that peak settlement rates occurred 22 days post-fertilisation at intermediate and high food levels but were delayed (until 29 days) at low food levels. However, at least some larvae were recorded to settle at 17 days post fertilization across all treatments. Overall survivorship and settlement rates were maximized at intermediate food levels $\left(1 \times 10^{4}\right.$ cells $\mathrm{mL}^{-1}$ of Proteomonas sulcata $)$ algal concentrations, and lowest at high $\left(1 \times 10^{5}\right.$ cells $\left.\cdot \mathrm{mL}^{-1}\right)$ food levels. There is little doubt that very low chlorophyll concentrations $\left(0-0.01 \mu \mathrm{g} \cdot \mathrm{L}^{-1}\right.$ chlorophyll) constrain food intake by CoTS $[17,20]$, and thereby potentially constrain growth, development and survival. However, CoTS larvae may be very resilient to limited food availability [16] and/or derive nutrients from prior maternal provisioning [33] or from other exogenous food sources [34,35], especially in the wild. Unlike Fabricius et al. [19] which showed that CoTS larvae failed to develop at chlorophyll concentrations $<0.25 \mu \mathrm{g} \cdot \mathrm{L}^{-1}$, we found limited effects on larval survivorship at chlorophyll concentrations of even $0.1 \mu \mathrm{g} \cdot \mathrm{L}^{-1}$, and at these low levels of food availability we still recorded moderate levels of settlement. These differences may be explained by variation in the chlorophyll concentrations of different microalgae, whereby cell densities used in the current study $\left(1-100 \times 10^{3} \mathrm{cells} \cdot \mathrm{mL}^{-1}\right)$ are very high relative to the cell densities used by Fabricius et al. [19], suggesting that $P$. sulcata has a very low cell specific chlorophyll concentration. Future studies should therefore focus on comparing specific cell densities, rather than using chlorophyll concentrations as a proxy for food availability. In the current study, high cell densities $\left(1 \times 10^{5}\right.$ cells. $\left.\mathrm{mL}^{-1}\right)$ were more deleterious for larval survival and settlement than the lowest cell densities $\left(1 \times 10^{3}\right.$ cells $\left.\cdot \mathrm{mL}^{-1}\right)$ tested.

Deleterious effects of excessive cell densities on planktotrophic larvae of CoTS were first apparent based on sustained declines in filtration rates with increasing cell densities above $100 \mathrm{cells} \cdot \mathrm{mL}^{-1}$ [17]. At very high cell densities $\left(>5 \times 10^{3}\right.$ cells $\left.\cdot \mathrm{mL}^{-1}\right)$, Lucas [17] noted that ingestion rates tended 
to plateau and only a fraction of algal cells were actually digested. Accordingly, CoTS larvae exposed to cell densities of $>5 \times 10^{3}$ cells $\cdot \mathrm{mL}^{-1}$ for Dunaliella primolecta and $>1 \times 10^{4}$ cells $\cdot \mathrm{mL}^{-1}$ for Phaeodactylum tricomutum had arrested development and poor survival [17]. Larvae may be overfed at extremely high cell densities, and the alimentary canal is so congested with cells that digestion is impeded and rates of assimilation are substantially reduced [17]. In bivalve cultures, overfeeding of larvae has resulted in increased incidence of bacterially related diseases [36]. However, it was considered very unlikely that CoTS larvae would ever be exposed to supra-optimal algal cell densities, and much more likely that larval development and survival would be constrained by low food availability [17]. Moreover, the highest algal concentrations used in this study $\left(10 \mu \mathrm{g} \cdot \mathrm{L}^{-1}\right.$ chlorophyll at cell densities of $1 \times 10^{5}$ cells. $\mathrm{mL}^{-1}$ of $P$. sulcata) are well beyond what would normally be expected on mid-shelf reefs of the GBR [37].

Chlorophyll concentrations recorded on or adjacent to coral reefs generally range from 0.2 to $0.6 \mathrm{\mu g} \cdot \mathrm{L}^{-1}[35,37]$, which are well below optimum levels for growth and survival of CoTS larvae $\left(1.0-4.0 \mu \mathrm{g} \cdot \mathrm{L}^{-1}\right.$ chlorophyll; $\left.[19,20]\right)$. At mid-shelf reefs on the GBR, for example, chlorophyll concentrations generally range from 0.2 to $0.5 \mu \mathrm{g} \cdot \mathrm{L}^{-1}$ (e.g., [37,38]) except on inshore (coastal) reefs or during extreme flood events. Moreover, chlorophyll concentrations in the wild do not accurately reflect the availability of phytoplankton (nanoplankton) prey for CoTS larvae, but are bolstered by significant quantities of picoplankton and microplankton (e.g., Furnas and Mitchell 1986). It is unclear however, whether these low levels of suitable prey would necessarily constrain larval survival and settlement. In our study, rates of survival for larvae up until 29 days post-fertilization (which is well beyond the period of peak settlement) at low phytoplankton concentrations $\left(0.1 \mu \mathrm{g} \cdot \mathrm{L}^{-1}\right.$ chlorophyll $)$ was still $>50 \%$ of that for intermediate food levels (Figure 1). This suggests that even during "normal" conditions, a significant portion of CoTS larvae could effectively settle on mid-shelf reefs on the GBR. While moderate increases in algal concentrations may enhance survival and settlement of CoTS, thereby potentially contributing to the initiation [19] and/or spread of population outbreaks [13], it seems unlikely that normally low nutrient concentrations and algal densities would be sufficiently low to actually prevent any CoTS larvae from completing development and effectively settling.

During extreme flood events, which are often considered to be potential triggers for initiating outbreaks on the GBR $[7,19]$, chlorophyll concentrations on inshore and mid-shelf reefs may exceed $10 \mu \mathrm{g} \cdot \mathrm{L}^{-1}$ [39]. In the extreme, chlorophyll concentrations $\geq 18 \mu \mathrm{g} \cdot \mathrm{L}^{-1}$ have been recorded along the leading edge of flood plumes [39], where conditions are optimal for phytoplankton production. Given increasing evidence of deleterious effects of high algal densities and chlorophyll concentrations, such events may actually constrain larval development and settlement for Acanthaster sp., rather than initiate outbreaks. Major flood events will also reduce salinity and increase levels of suspended sediment, which are also deleterious for development and survival of CoTS larvae (Caballes et al., Unpublished manuscript). It is clear however, that survival and settlement of CoTS larvae increases with moderate increases in chlorophyll concentrations (though limited data to resolve the optimum levels for performance of CoTS larvae) and given their exceptional reproductive potential [40], even small changes in the proportion of larvae that complete development and effectively settle will significantly affect the incidence, if not severity, of population outbreaks.

\subsection{Minimum and Maximum Competency Periods}

This study extends the maximum-recorded longevity (to 50 days) for CoTS larvae, and provides the first explicit evidence of extended competency for Acanthaster spp., up until 43 days post-fertilization. However, previous studies have tended to focus on the minimum pre-competency period [15] or more specifically, the minimum time taken for larvae to develop into late-stage brachiolaria which are assumed to be competent to settle [12], and generally do not consider the maximum competency period. In the current experiment, declines in the number of larvae after 30 days were caused by sustained settlement of competent larvae in experimental containers, as well as punctuated mortality events ("crashes") likely caused by instabilities in conditions. It is 
possible, therefore, under ideal conditions and with better constraints on spontaneous settlement, that larval longevity for CoTS might extend well beyond 50 days. Prolonged survival and competency will theoretically extend the maximum distances over which larvae can be dispersed [41], though maximum rates of settlement will nonetheless occur after relatively finite periods and probably close to natal reefs. At the medium (optimal) algal concentrations, after accounting for both larval survival and settlement rates, we found that peak settlement for $A$. cf. solaris tended to occur within 22 days post-settlement. It is possible, therefore, that few larvae would ever travel beyond the confines of individual reef systems, especially on the GBR, where there is high water retention and extensive reef habitat [42]. Rather, relatively rapid development of CoTS may promote high levels of self-recruitment, or at least significantly constrain dispersal among reefs.

This study had limited capacity to resolve differences in the minimum pre-competency period for CoTS larvae exposed to three different algal concentrations. Rather, competency was established only when late-stage brachiolaria larvae were observed across all treatments, thereby underestimating the minimum pre-competency period (17 days). Previous studies have shown that CoTS larvae can reach the late-stage brachiolaria stage within 9 to 11 days [43], though settlement has only ever been documented $\geq 14$ days post-fertilization [16]. This minimum pre-competency period is short relative to other echinoderms with planktotrophic larvae [44], which will enhance larval retention and relatively short-distance dispersal. On the GBR, the step-wise southerly progression of outbreaks suggests that dispersal is limited to $1-2$ degrees of latitude $(\sim 100-200 \mathrm{~km})$ per generation $[45,46]$, potentially representing the maximum geographic extent of dispersal for individual larvae.

Genetic differentiation apparent when comparing among populations of CoTS in different geographic regions (1000s of kilometers apart) suggest there are definitive constraints on larval dispersal at oceanic scales $[47,48]$. In the extreme, it is now clear that there are several distinct species of Acanthaster spp. [49,50], which must be maintained by limited larval and genetic exchange at these ocean scales. Within regions however, there is often very limited genetic structure [47,51-53], indicative of extensive genetic exchange via widespread dispersal of larvae. Timmers et al. [51] investigated genetic connectivity among CoTS populations in the northern Pacific, and revealed extensive gene flow along the $2500 \mathrm{~km}$ length of the Hawaiian archipelago, as well as between Hawai'i and Johnston Atoll separated by $865 \mathrm{~km}$. Similarly, Harrison et al. [53] found no genetic structure (using 27 optimized microsatellite loci) for outbreak populations of CoTS along the length of Australia's GBR. Distinct differences in levels of genetic structure within versus among regions, suggests that larvae are sufficiently long-lived so as to be effectively dispersed among reefs within regions, but largely incapable of dispersal among regions.

Existing connectivity models for CoTS $[7,8]$ use idealized particle dispersal periods (generally equivalent to PLDs) ranging from 1 to 28 days. While these particle dispersal periods were largely determined by logistical constraints of the models, rather than the larval biology of the study species, our study suggests that most CoTS larvae will generally settle within 22 days post-fertilization. Low productivity of near-reef waters [37] may delay larval development and peak settlement periods, though extended PLDs would be expected to lead to even higher rates of mortality in the field, owing to sustained levels of predation. While it is possible that some larvae could settle $>43$ days post fertilization, high rates of larval mortality (even higher than recorded in the current study due to additional impacts of predation) will take an inevitable toll on the number of larvae that persist after this period. It will be interesting to test whether refining existing connectivity models to take account of constrained estimates of settlement windows will alter predictions of connectivity and patterns in the spread of outbreaks. However, it is also necessary to try and establish the typical PLD for CoTS larvae settling on the GBR, specifically comparing whether there are differences in settlement patterns during the initiation versus spread of outbreaks. 


\section{Conclusions}

This study revealed significant differences in both larval survivorship and settlement rates for CoTS across two orders of magnitude variation in cell densities of the phytoplankton, Proteomonas sulcata. As expected, based on the larval starvation hypothesis, CoTS larvae exposed to very low food levels $\left(1 \times 10^{3}\right.$ cells. $\mathrm{mL}^{-1}$ of Proteomonas sulcata $)$ had lower survivorship and delayed development compared to larvae maintained in intermediate food levels $\left(1 \times 10^{4}\right.$ cells $\cdot \mathrm{mL}^{-1}$ of Proteomonas sulcata). Conversely, very high algal cell densities $\left(1 \times 10^{5}\right.$ cells $\cdot \mathrm{mL}^{-1}$ of Proteomonas sulcata $)$ did not accelerate development of CoTS larvae, nor extend their maximum competency period. Rather, very high algal concentrations had an overwhelmingly negative effect on CoTS larvae, resulting in much higher mortality rates from very early in larval development, compared to low and intermediate food levels. This study reaffirms that moderate increases in food availability (up to $1.0-4.0 \mu \mathrm{g} \cdot \mathrm{L}^{-1}$ chlorophyll, after accounting for the moderate contribution of suitable prey to field-based chlorophyll concentrations; $[19,20])$ may lead to increases in rates of development, survival and settlement for CoTS larvae. However, low levels of food availability may still enable significant rates of population replenishment and settlement, while the greatest constraints on growth and survival of CoTS larvae occurred at very high chlorophyll concentrations and phytoplankton densities.

Acknowledgments: This research was supported by an Advance Queensland Accelerate Partnership Grant, administered by the Queensland Government's Department of Science, Information Technology and Innovation. The manuscript benefitted greatly from discussions with Jon Brodie regarding realistic environmental conditions to which CoTS larvae will be naturally exposed.

Author Contributions: M.S.P. and S.D. conceived and designed the experiments; B.M. performed the experiments; S.B. analyzed the data; M.P., C.F.C. and C.A.T. wrote the paper; All authors edited the paper.

Conflicts of Interest: The authors declare no conflict of interest.

\section{References}

1. Scheltema, R.S. Larval dispersal as a means of genetic exchange between geographically separated populations of shallow-water benthic marine gastropods. Biol. Bull. 1971, 140, 284-322. [CrossRef]

2. Scheltema, R.S. Long-distance dispersal by planktonic larvae of shoal-water benthic invertebrates among central Pacific islands. Bull. Mar. Sci. 1986, 39, 241-256.

3. Lawton, R.J.; Messmer, V.; Pratchett, M.S.; Bay, L.K. High gene flow across large geographic scales reduces extinction risk for a highly specialised coral feeding butterflyfish. Mol. Ecol. 2011, 20, 3584-3598. [CrossRef] [PubMed]

4. Almany, G.R.; Berumen, M.L.; Thorrold, S.R.; Planes, S.; Jones, G.P. Local replenishment of coral reef fish populations in a marine reserve. Science 2007, 316, 742-744. [CrossRef] [PubMed]

5. Nanninga, G.B.; Berumen, M.L. The role of individual variation in marine larval dispersal. Front. Mar. Sci. 2014, 1, 71. [CrossRef]

6. Pratchett, M.S. Dynamics of an outbreak population of Acanthaster planci at Lizard Island, northern Great Barrier Reef (1995-1999). Coral Reefs 2005, 24, 453-462. [CrossRef]

7. Wooldridge, S.A.; Brodie, J.E. Environmental triggers for primary outbreaks of crown-of-thorns starfish on the Great Barrier Reef, Australia. Mar. Pollut. Bull. 2015, 101, 805-815. [CrossRef] [PubMed]

8. Hock, K.; Wolff, N.H.; Condie, S.A.; Anthony, K.R.N.; Mumby, P.J. Connectivity networks reveal the risks of crown-of-thorns starfish outbreaks on the Great Barrier Reef. J. Appl. Ecol. 2014, 51, 1188-1196. [CrossRef]

9. Victor, B.C. Settlement strategies and biogeography of reef fishes. In The Ecology of Fishes on Coral Reefs; Sale, P.F., Ed.; Academic Press: San Diego, CA, USA, 1991; pp. 231-260.

10. Richmond, R.H. Energetics, competency, and long-distance dispersal of planula larvae of the coral Pocillopora damicornis. Mar. Biol. 1987, 93, 527-533. [CrossRef]

11. Graham, E.M.; Baird, A.H.; Connolly, S.R. Survival dynamics of scleractinian coral larvae and implications for dispersal. Coral Reefs 2008, 27, 529-539. [CrossRef]

12. Henderson, J.A.; Lucas, J.S. Larval development and metamorphosis of Acanthaster planci (Asteroidea). Nature 1971, 232, 655-657. [CrossRef] [PubMed] 
13. Pratchett, M.S.; Caballes, C.F.; Rivera-Posada, J.A.; Sweatman, H.P.A. Limits to understanding and managing outbreaks of crown-of-thorns starfish (Acanthaster spp.). Oceanogr. Mar. Biol. Annu. Rev. 2014, 52, 133-200.

14. Lamare, M.D.; Pecorino, D.; Hardy, N.; Liddy, M.; Byrne, M.; Uthicke, S. The thermal tolerance of crown-of-thorns (Acanthaster planci) embryos and bipinnaria larvae: Implications for spatial and temporal variation in adult populations. Coral Reefs 2014, 33, 207-219. [CrossRef]

15. Uthicke, S.; Logan, M.; Liddy, M.; Francis, D.S.; Hardy, N.; Lamare, M.D. Climate change as an unexpected co-factor promoting coral eating seastar (Acanthaster planci) outbreaks. Sci. Rep. 2015, 5, 8402. [CrossRef] [PubMed]

16. Olson, R.R. In situ culturing as a test of the larval starvation hypothesis for the crown-of-thorns starfish, Acanthaster planci. Limnol. Oceanogr. 1987, 32, 895-904. [CrossRef]

17. Lucas, J.S. Quantitative studies of feeding and nutrition during larval development of the coral reef asteroid Acanthaster planci (L.). J. Exp. Mar. Biol. Ecol. 1982, 65, 173-193. [CrossRef]

18. Brodie, J.E.; Fabricius, K.E.; De'ath, G.; Okaji, K. Are increased nutrient inputs responsible for more outbreaks of crown-of-thorns starfish? An appraisal of the evidence. Mar. Pollut. Bull. 2005, 51, 266-278. [CrossRef] [PubMed]

19. Fabricius, K.E.; Okaji, K.; De'ath, G. Three lines of evidence to link outbreaks of the crown-of-thorns seastar Acanthaster planci to the release of larval food limitation. Coral Reefs 2010, 29, 593-605. [CrossRef]

20. Wolfe, K.; Graba-Landry, A.; Dworjanyn, S.A.; Byrne, M. Larval starvation to satiation: Influence of nutrient regime on the success of Acanthaster planci. PLOS ONE 2015, 10, 1-18. [CrossRef] [PubMed]

21. Haszprunar, G.; Spies, M. An integrative approach to the taxonomy of the crown-of-thorns starfish species group (Asteroidea: Acanthaster): A review of names and comparison to recent molecular data. Zootaxa 2014, 3841, 271-284. [CrossRef] [PubMed]

22. Kamya, P.Z.; Dworjanyn, S.A.; Hardy, N.; Mos, B.; Uthicke, S.; Byrne, M. Larvae of the coral eating crown-of-thorns starfish, Acanthaster planci in a warmer-high $\mathrm{CO}_{2}$ ocean. Glob. Chang. Biol. 2014, 20, 3365-3376. [CrossRef] [PubMed]

23. Okaji, K.; Ayukai, T.; Lucas, J.S. Selective feeding by larvae of the crown-of-thorns starfish, Acanthaster planci (L.). Coral Reefs 1997, 16, 47-50. [CrossRef]

24. Mellin, C.; Lugrin, C.; Okaji, K.; Francis, D.S.; Uthicke, S. Selective feeding and microalgal consumption rates by crown-of-thorns seastar (Acanthaster cf. solaris) larvae. Diversity 2016. under review.

25. Cowan, Z.L.; Dworjanyn, S.A.; Caballes, C.F.; Pratchett, M.S. Predation on crown-of-thorns starfish larvae by damselfishes. Coral Reefs 2016, 35, 1-10. [CrossRef]

26. Rumrill, S.S. Natural mortality of marine invertebrate larvae. Ophelia 1990, 32, 163-198. [CrossRef]

27. Mos, B.; Cowden, K.L.; Nielsen, S.J.; Dworjanyn, S.A. Do cues matter? Highly inductive settlement cues don't ensure high post-settlement survival in sea urchin aquaculture. PLoS ONE 2011, 6, e28054. [CrossRef] [PubMed]

28. Wood, S.N. Generalized Additive Models: An Introduction with R; CRC Press: Boca Raton, FL, USA, 2006.

29. Wood, S.N.; Scheipl, F. Gamm4: Generalized Additive Mixed Models Using mgcv and lme4. R Packag Version 0.2-3. Available online: http:/ /CRAN.R-project.org/package=gamm4 (accessed on 5 May 2016).

30. Fournier, D.A.; Skaug, H.J.; Ancheta, J.; Ianelli, J.; Magnusson, A.; Maunder, M.N.; Nielsen, A.; Sibert, J. AD Model Builder: Using automatic differentiation for statistical inference of highly parameterized complex nonlinear models. Optim. Methods Softw. 2012, 27, 233-249. [CrossRef]

31. Skaug, H.J.; Fournier, D.A.; Nielsen, A.; Magnusson, A.; Bolker, B.M. Generalized Linear Mixed Models using AD Model Builder. $R$ Package version 0.8.3.3. Available online: http:/ /glmmadmb.r-forge.r-project.org (accessed on 19 January 2016).

32. R Core Team. R: A Language and Environment for Statistical Computing; R Foundation for Statistical Computing: Vienna, Austria. Available online: http:/ /www.R-project.org/ (accessed on 21 June 2016).

33. Caballes, C.F.; Pratchett, M.S.; Kerr, A.M.; Rivera-Posada, J.A. The role of maternal nutrition on oocyte size and quality, with respect to early larval development in the coral-eating starfish, Acanthaster planci. PLoS ONE 2016, 11, e0158007. [CrossRef] [PubMed]

34. Hoegh-Guldberg, O. Uptake of dissolved organic matter by larval stage of the crown-of-thorns starfish Acanthaster planci. Mar. Biol. 1994, 120, 55-63.

35. Nakajima, R.; Nakatomi, N.; Kurihara, H.; Fox, M.; Smith, J.; Okaji, K. Crown-of-thorns starfish larvae can feed on organic matter released from corals. Diversity 2016, 8, 18. [CrossRef] 
36. Helm, M.M.; Bourne, N.; Lovatelli, A. Hatchery Culture of Bivalves: A Practical Manual; Food and Agriculture Organization of the United Nations: Rome, Italy, 2004.

37. Brodie, J.E.; De'ath, G.; Devlin, M.J.; Furnas, M.J.; Wright, M. Spatial and temporal patterns of near-surface chlorophyll a in the Great Barrier Reef lagoon. Mar. Freshw. Res. 2007, 58, 342-353. [CrossRef]

38. Wolanski, E.; Jones, M.; Williams, W.T.; Wolanski, E.; Jones, M.; Williams, W. Physical properties of the Great Barrier reef Lagoon waters near Townsville. II. Seasonal variations. Mar. Freshw. Res. 1981, 32, 321-334. [CrossRef]

39. Brodie, J.E.; Schroeder, T.; Rohde, K.; Faithful, J.; Masters, B.; Dekker, A.G.; Brando, V.E. Dispersal of suspended sediments and nutrients in the Great Barrier Reef lagoon during river discharge events: Conclusions from satellite remote sensing and concurrent flood plume sampling. Brodie Jon. Mar. Freshw. Res. 2010, 61, 651-664. [CrossRef]

40. Babcock, R.C.; Milton, D.A.; Pratchett, M.S. Relationships between size and reproductive output in the crown-of-thorns starfish. Mar. Biol. 2016, 163, 234. [CrossRef]

41. Luiz, O.J.; Allen, A.P.; Robertson, D.R.; Floeter, S.R.; Kulbicki, M.; Vigliola, L.; Becheler, R.; Madin, J.S. Adult and larval traits as determinants of geographic range size among tropical reef fishes. Proc. Natl. Acad. Sci. USA 2013, 110, 16498-16502. [CrossRef] [PubMed]

42. Wolanski, E.; Spagnol, S. Sticky waters in the Great Barrier Reef. Estuar. Coast. Shelf Sci. 2000, 50, $27-32$. [CrossRef]

43. Lucas, J.S. Environmental influences on the early development of Acanthaster planci (L.). In Crown-of-Thorns Starfish Seminar Proceedings; Austrlian Government Publishing Service: Canberra, Australia, 1974; pp. 109-121.

44. Strathmann, R.R. Length of pelagic period in echinoderms with feeding larvae from the Northeast Pacific. J. Exp. Mar. Bio. Ecol. 1978, 34, 23-27. [CrossRef]

45. Kenchington, R.A. Growth and recruitment of Acanthaster planci (L.) on the Great Barrier Reef. Biol. Conserv. 1977, 11, 103-118. [CrossRef]

46. Vanhatalo, J.; Hosack, G.R.; Sweatman, H.P.A. Spatio-temporal modelling of crown-of-thorns starfish outbreaks on the Great Barrier Reef to inform control strategies. J. Appl. Ecol. 2016. [CrossRef]

47. Yasuda, N.; Nagai, S.; Hamaguchi, M.; Okaji, K.; Gérard, K.; Nadaoka, K. Gene flow of Acanthaster planci (L.) in relation to ocean currents revealed by microsatellite analysis. Mol. Ecol. 2009, 18, 1574-1590. [CrossRef] [PubMed]

48. Timmers, M.A.; Bird, C.E.; Skillings, D.J.; Smouse, P.E.; Toonen, R.J. There's no place like home: Crown-of-thorns outbreaks in the central pacific are regionally derived and independent events. PLoS ONE 2012, 7, e31159. [CrossRef] [PubMed]

49. Vogler, C.; Benzie, J.A.H.; Lessios, H.A.; Barber, P.H.; Wörheide, G. A threat to coral reefs multiplied? Four species of crown-of-thorns starfish. Biol. Lett. 2008, 4, 696-699. [CrossRef] [PubMed]

50. Haszprunar, G.; Vogler, C.; Wörheide, G. Taxonomy does matter-A plea for the use of DNA-barcoding and barcode identification numbers when studying crown-of-thorns seastars (Acanthaster planci species complex). Diversity 2016, under review.

51. Timmers, M.A.; Andrews, K.R.; Bird, C.E.; DeMaintenton, M.J.; Brainard, R.E.; Toonen, R.J. Widespread dispersal of the crown-of-thorns sea Star, Acanthaster planci, across the Hawaiian Archipelago and Johnston Atoll. J. Mar. Biol. 2011, 2011, 1-10. [CrossRef]

52. Yasuda, N.; Taquet, C.; Nagai, S.; Yoshida, T.; Adjeroud, M. Genetic connectivity of the coral-eating sea star Acanthaster planci during the severe outbreak of 2006-2009 in the Society Islands, French Polynesia. Mar. Ecol. 2015, 36, 668-678. [CrossRef]

53. Harrison, H.B.; Pratchett, M.S.; Messmer, V.; Saenz-Agudelo, P.; Berumen, M.L. Microsatellites reveal genetic homogeneity among outbreak populations of crown-of-thorns starfish (Acanthaster cf. solaris) on Australia's Great Barrier Reef. Diversity 2016, under review.

(C) 2017 by the authors; licensee MDPI, Basel, Switzerland. This article is an open access article distributed under the terms and conditions of the Creative Commons Attribution (CC-BY) license (http://creativecommons.org/licenses/by/4.0/). 